\title{
Mutation scanning and genotyping by high- resolution DNA melting analysis in olive germplasm
}

\author{
Rosario Muleo, Maria Chiara Colao, Dario Miano, Marco Cirilli, Maria C. Intrieri, \\ Luciana Baldoni, and Eddo Rugini
}

\begin{abstract}
The application of high-resolution melting (HRM) analysis of DNA is reported for scanning and genotyping Olea europaea germplasm. To test the sensitivity of the method, a functional gene marker, phytochrome A (phyA), was used, since this gene is correlated with important traits for the ecology of the species. We have designed a set of oligos able to produce amplicons of 307 bp to scan for the presence of single polymorphic mutations in a specific phyA fragment encompassing the chromophore attachment site (Cys323). The presence of mutations for substitution, either homozygous or heterozygous, was easily detected by melting curve analysis in a high-resolution melter. It has been established that the sensitivity of the HRM analysis can be significantly improved designing specific primers very close to the mutation sites. All SNPs found were confirmed by sequence analyses and ARMS-PCR. The method has also been confirmed to be very powerful for the visualization of microsatellite (SSR) length polymorphisms. HRM analysis has a very high reproducibility and sensitivity for detecting SNPs and SSRs, allowing olive cultivar genotyping and resulting in an informative, easy, and low-cost method able to greatly reduce the operating time.

Key words: HRM, high-resolution melting, genotyping, melting curve analysis, SNP, ARMS-PCR.

Résumé : L'emploi de l'analyse de la dénaturation en haute résolution (HRM: « high-resolution melting ») de l'ADN est rapporté pour l'identification et le génotypage des ressources génétiques chez l'Olea europea. Pour évaluer la sensibilité de la méthode, un gène marqueur fonctionnel, phytochrome $\mathrm{A}(p h y A)$, a été employé puisque ce gène est corrélé avec plusieurs caractères importants en lien avec l'écologie chez cette espèce. Les auteurs ont développé un jeu d'amorces capables de produire des amplicons de $307 \mathrm{pb}$ permettant d'identifier la présence de simples mutations polymorphes au sein d'un fragment précis de phyA qui englobe le site d'attachement du chromophore (Cys323). La présence de substitutions à l'état homozygote ou hétérozygote était aisément détectée par analyse de la courbe de dénaturation produite par un appareil de dénaturation à haute résolution. Il a été établi qu'il était possible d'améliorer significativement la sensibilité de l'analyse HRM en employant des amorces situées très près des sites de mutation. Tous les SNP trouvés ont été confirmés par séquençage et par amplification PCR spécifique des allèles (ARMS-PCR). La méthode s'est aussi avérée très efficace pour mettre en évidence le polymorphisme de taille chez les microsatellites (SSR). L'analyse HRM offre une très grande reproductibilité et sensibilité pour la détection de SNP et de SSR ce qui permet le génotypage des cultivars et offre une méthode peu coûteuse et facile pour réduire le temps d'analyse.
\end{abstract}

Mots-clés : HRM, dénaturation en haute résolution, génotypage, analyse de la courbe de dénaturation, SNP. ARMS-PCR.

[Traduit par la Rédaction]

\section{Introduction}

Olive species exhibit a high level of genetic and phenotypic diversity (Bartolini et al. 1998). Genetic diversity has been examined using a variety of molecular approaches

Received 22 October 2008. Accepted 27 December 2008.

Published on the NRC Research Press Web site at

genome.nrc.ca on 12 February 2009.

Corresponding Editor: P. Donini.

R. Muleo, ${ }^{1}$ M.C. Colao, D. Miano, M. Cirilli, M.C. Intrieri, and E. Rugini. Department of Crop Production, Woody Plant Molecular Ecophysiology Laboratory, University of Tuscia-

Viterbo, Via S. Camillo de Lellis, 01100 Viterbo, Italy.

L. Baldoni. CNR, Institute of Plant Genetics, Via Madonna Alta

130, 06128 Perugia, Italy.

'Corresponding author (e-mail: muleo@unitus.it). based on allozyme polymorphisms (Lumaret et al. 2004), RAPD profiles and mithocondrial RFLPs (Besnard et al. 2002), AFLPs (Angiolillo et al. 1999; Belaj et al. 2003), simple sequence repeats (Rallo et al. 2000; Sefc et al. 2000; Cipriani et al. 2002), and polymorphisms in the intergenic spacer of chloroplast DNA (Intrieri et al. 2007). The techniques listed above are powerful, but their analysis is usually complex and time consuming and the markers are often anonymous.

Recently, many methods have been developed to detect single nucleotide polymorphisms (SNPs), which represent the next generation of plant markers (Hess et al. 2000). The use of SNPs is expected to lead to a better understanding of the genetic basis for complex characters, such as plant productivity, development, and adaptation to abiotic and biotic stresses, and could be essential for genetic improvement programmes. Genes of known sequences that influence a trait 